\title{
Analysis of cadmium in sodium hypochlorite solutions by Anodic Stripping Voltammetry test: a preliminary study
}

Charliani Menegassi Marostegan ${ }^{\mathrm{a}}$, Renata Grazziotin-Soares ${ }^{c}$, Diego Machado Ardenghi ${ }^{\mathrm{c}}$, José Antônio Poli de Figueiredo ${ }^{d}$, Tiago André Fontoura de Melo ${ }^{b}$

\begin{abstract}
OBJECTIVE: The literature reports that Cadmium (Cd) is highly toxic to human body and dental tissues. Sodium hypochlorite $(\mathrm{NaOCl})$ irrigating solutions used in root canal treatment are composed of several metals. However, there is no study regarding the presence of $\mathrm{Cd}$ in these solutions. This study aimed to verify the existence of $\mathrm{Cd}$ on $2.5 \% \mathrm{NaOCl}$ solutions proceeding from different origins, being to date the first of the kind.

METHODS: Three solutions of $2.5 \% \mathrm{NaOCl}$ from different origins were assessed in relation to the chlorine content and the presence/amount ( $\mathrm{mg} / \mathrm{L}$ ) of cadmium by the Anodic Stripping Voltammetry (ASV) test. Oxidation-Reduction Titration (OR) method was performed to quantify the available chlorine. The types of $\mathrm{NaOCl}$ solutions were from: i) hand manipulated at a pharmacy, ii) industrialized and commercialized at a dental supply store and iii) industrialized and commercialized at a grocery supermarket.

RESULTS: The ASV test showed the amount of cadmium was $0.14 \mathrm{mg} / \mathrm{L}$ for solutions coming from the pharmacy and the supermarket, and $0.13 \mathrm{mg} / \mathrm{L}$ for the solution coming from the dental supply store. OR method found the following amount of available chlorine: $1.15 \%$ and $1.52 \%$ and $2.24 \% \mathrm{NaOCl}$ for solutions proceeding from the pharmacy, dental supply store and supermarket, respectively. CONCLUSION: All samples presented levels of $\mathrm{Cd}$ above the permissible limits stated by the legislation from where the study was conducted $(0.01 \mathrm{mg} / \mathrm{L})$.
\end{abstract}

Key words: Endodontics; Cadmium; Sodium hypochlorite; Human body

\section{Análise de cádmio em soluções de hipoclorito de sódio por Voltametria de Redissolução Anódica: um estudo preliminar}

\section{RESUMO}

OBJETIVO: A literatura relata que o Cadmio (Cd) é altamente tóxico para o corpo humano e para os tecidos dentais. Soluçães irrigadoras como o hipoclorito de sódio $(\mathrm{NaOCl})$ usadas no tratamento de canal radicular são compostas por diversos metais. Contudo, não há estudo em relação à presença de $\mathrm{Cd}$ nestas soluções. Este estudo objetivou verificar a existência de $\mathrm{Cd}$ em soluções de $\mathrm{NaOCl} 2.5 \%$ procedentes de diferentes origens, sendo até o momento, o primeiro estudo deste tipo.

MÉTODOS: Três soluções de $2.5 \%$ de $\mathrm{NaOCl}$ de diferentes origens foram avaliadas em relação ao conteúdo de cloro e a presença/quantidade (mg/L) de Cd por meio do teste de Voltametria de Redissolução Anódica (ASV). O método de Titulação Oxidação-redução (OR) foi empregado para quantificar o cloro livre. Os tipos das soluções de $\mathrm{NaOCl}$ foram provenientes das seguintes origens: i) manipuladas em farmácia, ii) industrializada e comercializada em dentárias, e iii) industrializada e comercializada em supermercados.

RESULTADOS: O teste ASV mostrou que a quantidade de Cd era de $0.14 \mathrm{mg} / \mathrm{L}$ para soluções provenientes da dentária. O método OR encontrou a seguinte quantidade de cloro livre: 1.15\%; 1.52\% e 2.24\% para as soluções provenientes da farmácia, dentária e supermercado, respectivamente.

CONCLUSÃO: Todas as amostras apresentaram níveis de Cd acima dos limites permitidos pela legislação do local onde o estudo foi conduzido $(0.01 \mathrm{mg} / \mathrm{L})$.

Palavras chave: Endodontia; Cádmio; Hipoclorito de sódio; Corpo humano a São Leopoldo Mandic, Porto Alegre, Brazil b Universidade Federal do Rio Grande do Sul, Porto Alegre, Brazil

' University of Saskatchewan, SK, Canada

d Pontifícia Universidade Católica do Rio Grande do Sul, Porto Alegre, Brazil 


\section{INTRODUCTION}

Cadmium (Cd) is one of most toxic metals found in the Earth's crust. This heavy metal is classified by the International Agency for Research on Cancer (IARC) as "Group 1 Carcinogens", which means that, there is sufficient evidence to confirm that the substance is carcinogenic for human beings. The growing concern with $\mathrm{Cd}$ is a result of its high toxicity [1]. Cd is toxic even when the metal is present on substances and materials in very low concentrations. In addition to that, $\mathrm{Cd}$ has a long half-life in the human body, remaining in it from 10 to 30 years [2], and it can be deposited in the heart, spleen, testicles and pancreas [3-5]. Cd-contamination might lead to fetal abnormalities, alterations in the nervous system [6], cardiovascular disorders (arteriosclerosis and hypertension) [7]; and lung, kidneys and prostate neoplasias [8], as well as, it might impair the metabolism of calcium [9], resulting in osteoporosis [10,11].

Additionally, since the $70 \mathrm{~s}$, laboratorial studies have shown that systemic contamination with $\mathrm{Cd}$ resulted in harmful alterations in oral tissues. After successive $\mathrm{Cd}$ injections in rats, the metal was deposited in teeth and bones [12], impairing the dental matrix [13], leading to a reduction in odontoblasts-cells [14] and causing discoloration of incisors [15]. Similarly, after endovenous injection of a Cd-containing compound ( 1 and $2 \mathrm{mg} / \mathrm{kg}$ ) for 13 weeks in rats, the histopathologic analysis showed local alterations on teeth: destruction of the enamel organ, $\mathrm{Cd}$ accumulation and iron loss. Moreover, this same study showed that total pulp necrosis occurred not only in incisors but also in molars. The pulp of molars was slightly intoxicated with $\mathrm{Cd}$, which might be responsible for the ischaemia and subsequently necrosis [15]. Recently, authors showed that toxic heavy metals accumulation (including $\mathrm{Cd}$ ) in supragingival dental calculus of smokers was significantly higher that in nonsmokers. They stated that smoking is a major environmental source for chronic toxic heavy metal exposition [16].

In the Dentistry field, evidences have suggested that $\mathrm{Cd}$ might incorporate in dental instruments/materials during the manufacturing process. $\mathrm{Cd}$ has already been found in dental impression materials, such as alginate $[17,18]$, in pigments of acrylic resin, amalgam, orthodontic alloys [19], in Portland and MTA-based cements [20,21], as well as, in gutta-percha points $[22,23]$. In this regard, although Flachsenberg and Hülsmann [24] have showed the absence of $\mathrm{Cd}$ in human periapical tissues after apicoectomy of teeth with root canal fillings, this toxic heavy metal, when present in the endodontic materials/substances, might overflow to the periapical tissues, being harmful to people.

In endodontics, the irrigation of root canal with sodium hypochlorite $(\mathrm{NaOCl})$ might be potentially dangerous to patients, dentists and dental staff. Because of the adequate properties of $\mathrm{NaOCl}$, (ability to reduce surface tension, ability to neutralize toxic products, double detergent action, lubricant and clarifier action and, mainly, its capacity to solubilize organic tissues and its broad antimicrobial spectrum), this substance is widely used and it is considered as a first choice irrigation solution in most countries [25]. $\mathrm{NaOCl}$ solutions used in root canal treatment are composed of several metals, however, to the best of our knowledge, there is no study regarding the presence of $\mathrm{Cd}$ in these solutions.

Considering the clinical relevance of the presence of $\mathrm{Cd}$ in dental instruments/materials/substances, being able to contaminate patients and staff, added to the lack of studies investigating $\mathrm{Cd}$ in $\mathrm{NaOCl}$ irrigating solutions, this study aimed to verify, by Anodic Stripping Voltammetry (ASV) test, the presence/absence of $\mathrm{Cd}$ in $2.5 \% \mathrm{NaOCl}$ solutions proceeding from different origins. A secondary aim was to assess the chlorine content of those solutions.

The null hypothesis tested was that the amount of $\mathrm{Cd}$ encountered in all samples tested was below the permissible limits stated by local legislation.

\section{METHODS}

\section{Samples acquisition}

Three samples of $2.5 \% \mathrm{NaOCl}$ proceeding from different origins were analyzed in regard of the presence/absence of $\mathrm{Cd}$. If Cd were present, the amount was recorded (percentage). The origins of the solutions were: i) hand manipulated at a pharmacy, ii) industrialized and commercialized at a dental supply store, and iii) industrialized and commercialized at a grocery supermarket.

The 2.5\% $\mathrm{NaOCl}$ solutions brands were as follows: i) Bulla ${ }^{\circledR}$ Manipulation, Porto Alegre RS, Brazil, batch reference number: 097213, date of manufacture: 01/24/2014, expiry date: $07 / 23 / 2014$; ii) Iodontosul ${ }^{\circledR}$ Industrial Odontologica do Sul Ltd., Porto Alegre RS, Brazil, batch reference number: 1406, date of manufacture: 01/22/2014, expiry date: 01/22/2015; and iii) QBoa $^{\circledR}$, Osasco SP, Brazil, batch reference number: 0079, date of manufacture: 01/13/2014, expiry date: 07/12/2014.

\section{Anodic Stripping Voltammetry test (ASV) \& Oxidation-Reduction Titration method (OR)}

ASV test was performed to verify presence/absence and the amount of $\mathrm{Cd}$ in $2.5 \% \mathrm{NaOCl}$ solutions. The samples were analyzed using the differential pulse anodic stripping voltammetry technique with the following parameters: scanning between $0.8 \mathrm{~V}$ and $0.2 \mathrm{~V}$ and speed of $0.06 \mathrm{~V}$.

OR method was performed to quantify the available chlorine. This method, also called Iodometric Titration, is very non-specific for oxidants and it is used for total chlorine testing at levels above $1 \mathrm{mg} / \mathrm{L} \mathrm{Cl}_{2}$. OR method is described at the British pharmacopoeia (https://www.pharmacopoeia.com).

For both tests, each sample was subjected to analysis in triplicate. Data were reported descriptively.

\section{RESULTS}

ASV test showed the presence of $\mathrm{Cd}$ in all samples analyzed. The $\mathrm{Cd}$ amount and the amount (percentage) of available chlorine are shown in Table $\mathbf{1}$. 
Table 1. Cadmium (Cd) amount (mg/L) and amount (\%) of available chlorine for the $\mathrm{NaOCl}$ solution proceeding from different origins

\begin{tabular}{lccc}
\hline Origin of 2.5\% NaOCl solution & $\begin{array}{c}\text { Oxidation-Reduction Titration } \\
\text { method (OR) } \\
\text { Available chlorine (\%) }\end{array}$ & $\begin{array}{c}\text { Anodic Stripping Voltammetry } \\
\text { test (ASV) } \\
\text { Cd amount (mg/L) }\end{array}$ & $\begin{array}{c}\text { Cd permissible limits stated by } \\
\text { the legislation from where the } \\
\text { study was conducted (mg/L) }\end{array}$ \\
Pharmacy & 1.15 & 0.14 & 0.13 \\
Dental supply store & 1.52 & 0.13 & 0.14 \\
Supermarket & 2.24 & 01 & \\
\hline
\end{tabular}

\section{DISCUSSION}

This study was motivated by the extreme clinical importance that the presence of $\mathrm{Cd}$ into $\mathrm{NaOCl}$ solutions has on the deterioration of human health, being a potential hazard for patients, dentists and dental staff. The inexistence of studies addressed to this subject prompted us to conduct this preliminary investigation, which arose the possibility to foster further research expanding this topic.

This investigation showed that all samples presented levels of $\mathrm{Cd}$ much above the permissible limits stated by the Brazilian legislation, which rejects the null hypothesis. Additionally, the amount of available chlorine was lower than expected for all samples, mainly, for the pharmacy and dental supply store solutions.

$\mathrm{NaOCl}$ solutions industrialized and commercialized at supermarkets (used as a domestic bleach) are manufactured with the water from the city supplier, which is rich in metallic ions. On the other hand, the solutions prepared in laboratories (from the pharmacy and dental materials stores) are manufactured with bi-distilled water, which is a poor source of heavy metals. In this regard, $\mathrm{NaOCl}$ solution from the supermarket should have higher amount of $\mathrm{Cd}$ when compared to the pharmacy and dental materials solutions. However, this fact was not shown in this study.

Because of the inexistence of studies that investigates $\mathrm{Cd}$ in $\mathrm{NaOCl}$ solutions, the $\mathrm{Cd}$ concentration in several dental materials may work as a parameter for our results. A study measured $0.017 \%$ and $0.025 \%$ of Cd-mass in two different commercial brands of alginate commercialized in Australia [17]. More recently, authors measured the $\mathrm{Cd}$ content in MTA-based cements, showing the following results: $0.10 \pm 0.01$ p.p.m (which means $0.00001 \%$ ) in Ortho MTA and $0.16 \pm 0.01$ p.p.m (which means $0.000016 \%$ ) in ProRoot MTA [21]. Another investigation measured the amount of $\mathrm{Cd}$ in $\mathrm{mg} / \mathrm{kg}: 2.97 \pm 0.23$ in Grey Portland cement; $2.09 \pm 0.04$ in Grey ProRoot MTA; 0.35 \pm 0.28 in White Portland cement and $0.23 \pm 0.19$ in White ProRoot MTA [20]. Moller and Orstavik [22], studying gutta-percha points stated that the presence of $\mathrm{Cd}$ up to $0.6 \%$ is notable for several reasons, including its high toxicity and the possibility to impair physical and chemical properties of any biomaterial. For gutta-percha points, the source of $\mathrm{Cd}$ may appear as a contamination with zinc, or it may be added as a color pigment intentionally.
The excessive amount of $\mathrm{Cd}$ present into $\mathrm{NaOCl}$ solutions is a concern for patients having endodontic treatment because the solution contacts with the root canal system and it stays very close to the periapical tissues.

Although the protection of the patient with the rubber dam during the endodontic procedures, accidents with $\mathrm{NaOCl}$ can occur [26], leading the patient skin, mucosa and dental tissues directly exposed to the toxicity of $\mathrm{Cd}$. When an accidental injection of $\mathrm{NaOCl}$ beyond the apical foramen occurs, the $\mathrm{Cd}$ might cause injuries to the patient's periodontal ligament, cells, connective tissue, bone etc [27]. The toxic effects of $\mathrm{Cd}$ on the cells derived from the human periodontal ligament have been demonstrated by the inhibition of cell growth [28]. Additionally, the susceptibility of the periodontal ligament to the effects of $\mathrm{Cd}$ contamination was showed in juvenile rats that ingested $\mathrm{Cd}$ during the breastfeeding period: narrowing of the periodontal ligament space, disorganization of the connective tissue and blood vessels, with less collagen fibers and more connective tissue, characterizing an edema situation [29]. Although a previous study have showed absence of $\mathrm{Cd}$ (proceeding from guttapercha and endodontic sealers) in the periapical tissues of patients with root canal fillings [24], it is important to highlight that this situation is different from an overflow of $\mathrm{NaOCl}$ into the periapical region. $\mathrm{A} \mathrm{NaOCl}$ solution is a liquid substance, different from the obturation materials, so, the contamination of patient's tissues with heavy metals might be much more likely to happen with the use of $\mathrm{NaOCl}$ solution.

Accidents with $\mathrm{NaOCl}$ solutions might possibly promote atrophy in the patient's skin and mucosa cells, being the $\mathrm{Cd}$, an additional aggravating factor for the irritability of the $\mathrm{NaOCl}$. Even though the available evidences have not been studied the effects of the direct contact of Cd-containing substances at skin and/or mucosae, authors showed epithelial atrophy in newborn rats ' oral mucosa as a result from 21 days of ingestion of $300 \mathrm{mg} / \mathrm{L} \mathrm{Cd}$-chloride by the adult mother [30].

The lower amount of available chlorine measured compared with the amount stated by the product label has already demonstrated by other researchers, when they investigated $\mathrm{NaOCl}$ solutions commercialized in the Netherlands [31]. This study showed that the amount of $\mathrm{Cd}$ was similar between the solutions with different percentage of available chlorine $(1.15 \% \mathrm{NaOCL}$ from the pharmacy had 
$0.14 \mathrm{mg} / \mathrm{L}$ of $\mathrm{Cd}$, while $2.24 \% \mathrm{NaOCl}$ from the supermarket had also $0.14 \mathrm{mg} / \mathrm{L}$ of $\mathrm{Cd}$ ). It can be hypothesized that the chlorine concentration does not have importance regarding the $\mathrm{Cd}$ amount, at least in part, for that $\mathrm{NaOCl}$ solutions commercialized in the region where this experiment took place.

Inhalation of $\mathrm{NaOCl}$ solution, and, consequently inhalation of $\mathrm{Cd}$, is probable to occur when the rubber dam is not appropriately positioned over the patient's nose. It is known that the inhaled $\mathrm{Cd}$ is absorbed in a higher amount that the swallowed $\mathrm{Cd}$ [32], leading to disruption in mitochondrial functions [33] and interfering with the transportation and metabolism of other metals that are important to the human body, such as, iron and copper [34]. It is essential to know that the permissive limit of $\mathrm{Cd}$ in drinking water is very low, and it should not exceed $0.003 \mathrm{mg} / \mathrm{L}$ according to the World Health Organization. The total intake of cadmium should not exceed $1 \mu \mathrm{g} / \mathrm{kg}$ of body weight per day [35].

The ASV test used in this study is very sensitive and reproducible method for trace metal ion analysis in aqueous media. Approximately 12-15 metal ions can be tested through this method. Additionally, ASV analysis is useful to detect heavy metals in very diluted solutions $[36,37]$.

\section{CONCLUSIONS}

In sum, this preliminary study, in spite of the small number of samples analyzed, was able to inform dental professionals and researchers in relation to the high amount of $\mathrm{Cd}$ encountered in $\mathrm{NaOCl}$ solutions, which is potentially dangerous to people. This finding should be a reason for a more meticulous inspection and control of $\mathrm{NaOCl}$ solutions manufactured by Brazilian companies/corporations. Moreover, this study was the first one to measure the $\mathrm{Cd}$ amount in $\mathrm{NaOCl}$ solutions used in endodontic daily practice, as well as, to present the ASV test as suitable to investigate heavy metals in $\mathrm{NaOCl}$ solution. Our investigation is pioneer and foster further research to study not only different origins and concentrations of $\mathrm{NaOCl}$ solutions, but also, other types of irrigating, solutions

\section{REFERENCES}

1. Waalkes MP. Cadmiun Carcinogenesis in Review. Journal Inorg Biochem. 2000;79:241-4.

2. Lyons-Alcantara M, Tarazona JV, Molthersill C. The differential effects of cadmium exposure on the growth and surgical of primary and established cells from fish and mammals. Cell Biol Toxicol. 1996;12:29-38.

3. Berlin M, Ullberg S. The fate of Cd 109 in the mouse. Arch Environ Health 1963:7:72-9

4. Schwartz GG, Reis IM. Is cadmium a cause of human pancreatic cancer? Cancer Epidemiol Biomarkers Prev. 2000;9:139-45.

5. Gunnarsson D, Nordberg G, Selstam G. Differential effects of cadmium on the gene expression of seven-transmembrane spanning receptors and GAPDH in the rat testis. Toxicol Lett 2007:168:51-7.

6. Viaene MK, Rollo HA, Leenders J, De Groof M, Swerts LJ, Lison D, Masschelein R. Cadmium: a possible etiological factor in peripheral polyneuropathy. Neurotoxicology. 1999;20:7-16

7. Satarug S, Nishijo M, Ujijin P, Vanavanitkun Y, Moore MR. Cadmiuminduced nephoropathy in the development of high blood pressure. Toxicol Lett. 2005;157:57-68.
8. Roe FJC, Dukes CE, Cameron KM, Pugh RCB, Mitcheley BCV. Cadmium neoplasia: testicular atrophy and Leydig cell hyperplasia and neoplasia in rats and mice following the subcutaneous injection of cadmium salts. Br J Cancer. 1964;18:674 81.

9. Christoffersen J, Christoffersen MR, Larsen R, Rostrup E, Tingsgaard P. Andersen O, Grandjean P. Interaction of cadmium ions with calcium hydroxyapatite crystals: a possible mechanism contributing to the pathogenesis of cadmium induced bone diseases. Calcif Tissue Int. 1988;42:331-9.

10. Alfven T, Elinder CG, Carlsson MD, Grubb A, Hellstrom L, Persson B Pettersson C, Spang G, Schutz A, Järup L. Low-level cadmium exposure and osteoporosis. J Bone Miner Res. 2000;15:1579-86.

11. Regunathan A, Cerny EA, Villarreal J, Bhattacharyya MH. Role of fos and src in cadmium-induced decreases in bone mineral content in mice. Toxicol Appl Pharmacol. 2002;185:25-40.

12. Bawden JW, Hammarström LE. Distribution of cadmium in developing teeth and bone of young rats. Scand J Dent Res. 1975;83: 179-86.

13. Suda T, Horiuchi N, Ogata E, Ezawa I, Otaki N, Kimura M. FEBS Letters. 1974;42:23-6

14. Furuta $\mathrm{H}$. Cadmium effects on bone and dental tissues of rats in acute and subacute poisoning. Experientia. 1978;34:1317-8

15. Katsuta $\mathrm{O}$, Hiratsuka $\mathrm{H}$, Matsumoto J, Tsuchitani M, Umemura T. Cadmium induced dental lesions in ovariectomized rats. Toxicol Pathol. 1996;24 451-7

16. Yaprak E, Yolcubal I, Sinanoğlu A, Doğrul-Demiray A, GuzeldemirAkcakanat E, Marakoğlu I. High levels of heavy metal accumulation in dental calculus of smokers: a pilot inductively coupled plasma mass spectrometry study. Periodontal Res. 2017;52:83-8.

17. Freitas JF. Potential toxicants in alginate powders. Aust Den J. 1980;25 224-8

18. Braga AS, Catirse ABCEB, Vaz LG, Spadaro ACC. Quantitative analysis of potentially toxic metals in alginates for dental use. Rev Cien Farm Basica Apl. 2005;26:125-30.

19. Brune D. Metal release from dental biomaterials. Biomaterials 1986;7 163-75.

20. Chang SW, Shon WJ, Lee W, Kum KY, Baek SH, Bae KS. Analysis of heavy metal contents in gray and white MTA and 2 kinds of Portland cement: a preliminary study. Oral Surg Oral Med Oral Pathol Oral Radiol Endod. 2010;109:642-6

21. Kum KY, Zhu Q, Safavi K, Gu Y, Bae KS, Chang SW. Analysis of six heavy metals in Ortho mineral trioxide aggregate and ProRoot mineral trioxide aggregate by inductively coupled plasma-optical emission spectrometry. Aust Endod J. 2013:39:126-30.

22. Moller B, Orstavik D. Chemical and energy-dispersive X-ray analyses of Gutta percha points. J Endod. 1984;10:413-6.

23. Molokhia A, Lilley JD. Unusual levels of trace elements in dental filling materials. An investigation by neutron activation analysis. Acta Pharmacol Toxicol. 1986;59 Suppl 7:56-9

24. Flachsenberg S, Hülsmann M. Comparative analysis of lead and cadmium in the periapical tissue of teeth with and without root filling. Endod Practice Today. 2008;2:267-72

25. Zehnder M. Root canal irrigants. J Endod. 2006;32:389-98

26. Regalado Farreras DC, Puente CG, Estrela C. Sodium hypochlorite chemical burn in an endodontist's eye during canal treatment using operating microscope. J Endod. 2014;40:1275-9.

27. Baldwin VE, Jarad FD, Balmer C, Mair LH. Inadvertent injection of sodium hypochlorite into the periradicular tissues during root canal treatment. Dent Update. 2009:36:14-6, 19

28. Hayama Y. Effect of heavy metal ions on the cells derived from human periodontal ligament. Effects of $\mathrm{Pb}$ and $\mathrm{Cd}$. Kanagawa Shigaku.1990;24:671-91.

29. Ribas JP, Lopes RA, Sala MA, Ribas LMR, Vitti M, Regalo SCH. Acción del cádmio durante la lactancia sobre el periodonto de rata. Archivos de la Facultad de Medicina de Zaragoza. 2006;46:3-6.

30. Picoli LC, Watanabe I, Lopes RA, Sala MA, Picoli F. Efectos del cadmio en la mucosa yugal de la rata durante la lactancia. Estudio morfológico e histométrico. Int J Morfol. 2003:21:191-8.

31. Van der Waal S, Connert T, Laheij A, de Soet J, Wesselink P. Free available chlorine concentration in sodium hypochlorite solutions obtained from dental practices and intended for endodontic irrigation: are the expectations true? Quintessence Int. 2014;45:467-74.

32. Friberg L, Piscator M, Nordberg GF, Kjellström T. Cadmium in the environment. 2 ${ }^{\mathrm{a}}$ ed. Cleveland, CRC Press; 1974

33. Miccadei S, Floridi A. Sites of inhibition of mitochondrial electron transport by cadmium. Chem Biol Interact. 1993;89:159-67. 
34. Chang, L. The concept of direct and indirect neurotoxicity and the concept of toxic metal/ essential element interactions as a common biomechanism underlying metal toxicity. Vul Brain Environ Risks. 1992;2:61-82.

35. WHO - World Heath Organization 2011 website. Cadmium in Drinking Water. Background document for development of WHO Guidelines for Drinking-water quality. Available at: http://www.who.int/water_sanitation_ health/dwq/chemicals/cadmium.pdf

36. Rusinek CA, Bange A, Papautsky I, Heineman WR. Cloud Point Extraction for Electroanalysis: Anodic Stripping Voltammetry of Cadmium. Anal Chem. 2015:87:6133-40
37. Shahbazi $Y$, Ahmadi F, Fakhari F. Voltammetric determination of $\mathrm{Pb}, \mathrm{Cd}$ $\mathrm{Zn}, \mathrm{Cu}$ and Se in milk and dairy products collected from Iran: An emphasis on permissible limits and risk assessment of exposure to heavy metals. Food Chem. 2016;192:1060-7. 